\title{
The Effect of Profitability on Dividend Policy and Firm Value: A Case Study of Indonesian Manufacturing Company
}

\author{
Bambang Widjanarko Susilo ${ }^{1}$, Grahita Chandrarin ${ }^{2}$, and Prihat Asih $^{3}$ \\ ${ }^{1}$ Doctoral Student of Postgraduate Program of University Malang Indonesia \\ ${ }^{2,3}$ Lecturer of Postgraduate Program of University of Merdeka Malang Indonesia
}

\begin{abstract}
This research was conducted to examine the effect of profitability on firm value through the dividend policy of manufacturing companies listed on the IDX for the 2015-2018 period. The analysis was carried out using secondary data, namely financial reports on the Indonesian Stock Exchange. The technique used in sampling is purposive sampling. The number of samples obtained was 27 manufacturing companies. The analysis technique uses path analysis. The results of the analysis show that profitability has a positive (significant) effect on dividend policy, dividend policy has an effect on firm value, and dividend policy no effect mediate between profitability and firm value.
\end{abstract}

Keywords: Profitability, Dividend Policy, Firm Value.

\section{INTRODUCTION}

Companies with high profitability will have a greater opportunity to remain a going concern in industry competition. Going concern is the sustainability of every company when it is founded with the hope and goal of the company being able to compete and develop for a long period of time and be able to survive and maintain its business continuity. The level of prosperity of shareholders and investors is reflected in the value of the company. Firm value can also be an important perceptual indicator of company performance (Fama et al., (1978) and it is reflected in stock price movements. The share price of the company causes the wealth of shareholders to increase or decrease. The level of prosperity of shareholders and investors is reflected in the value of the company. The value of the company can also be an important perception indicator of the company's performance and it is reflected in the movement of stock prices. The company's stock price causes shareholder wealth to increase or decrease (Fama et al., (1978) [1].

Rao, and Stevens (2007) say that the value of the company is influenced by the financial side by dividend policy, corporate tax, profitability and leverage [3]. Profitability can be an important consideration for investors in their investment decisions. With an offer to get a high profit, it is expected to attract investors to invest. The higher the level of profitability, the greater the possibility of dividend distribution (Thamrin, et al, 2017) [4].

Companies with profitability reflect the company's success in obtaining company profits and it provides an exit effect for investors so that they can increase the value of the company. (Thamrin, et al, 2017)[4]. On the other hand, dividend policy is one of the factors that greatly affects the increase in the value of the company, so that the value of the company. profitability, dividend policy and firm value are very important. But in practice this is not as expected, manufacturing companies listed on the IDX show a different phenomenon from the theory above, here are the data on the average firm value, profitability and dividend policy of 
manufacturing companies in 2015-2018.

Table 1 Dividend Policy, Firm Value, Profitability, Manufacturing 2015-2018

\begin{tabular}{|l|l|l|l|}
\hline Rata-rata & $\begin{array}{l}\text { DIVIDEN } \\
\text { (DPR) }\end{array}$ & $\begin{array}{l}\text { NILAI } \\
\text { PERUSA } \\
\text { HAAN } \\
\text { (PBV) }\end{array}$ & $\begin{array}{l}\text { PROF } \\
\text { (ROE) }\end{array}$ \\
\hline $\mathbf{2 0 1 5}$ & 45.056 & 5.713 & 20.753 \\
\hline $\mathbf{2 0 1 6}$ & 5.713 & 6.454 & 22.282 \\
\hline $\mathbf{2 0 1 7}$ & 6.454 & 7.167 & 21.042 \\
\hline 2018 & 7.167 & 6.18 & 16.431 \\
\hline \multicolumn{3}{|l|}{ Sumber : Data IDX yang diolah (2021) }
\end{tabular}

Profitability (measured by ROE proxy) has decreased inversely with firm value, a business phenomenon contradicts the theory with increasing profitability, the higher the firm value (Brigham and Houston (2007))[13]. Dividend policy (measured by the DPR proxy) has decreased, in contrast to the company's value that experienced ups and downs and finally increased, while the value of profitability decreased. If the dividend policy decreases, it will have an effect on investors while the company value increases, which is contrary to the opinion of (Gordon (1963)[5] and (Litner (1956) [6]).

Research on the effect of profitability on firm value is still a difference of opinion (research gap). Rasyid (2015)[2]; Chen,L,J and Chen,S.Y.(2011)[7];Oktaviani (2019)[8] significant effect of profitability on firm value, but different from the study. Sulastri, et al (2014)[14];Hirdinis,M (2019)[9] profitability is not significantly related to firm value. This paper aims to examine the effect of profitability on dividend policy and firm value.

\section{THEORITICAL REVIEW}

\section{a. The value of the company}

Firm value is representative or a reflection of the market price of the company's common stock, which in turn is the result of the company's investment, funding, and dividend decision functions (Horne, 2002)[15]. Firm value is measured by the Price to book value (PBV) proxy, with the increasing share price, the PBV will also increase compared to Shim and Siegel (2007) book value per share (2007)[16].

\section{b. Profitability}

Profitability is the ability of the company's performance to earn income through its business operations using equity funds owned by the shareholders, and profitability is the end result of a number of management policies and decisions (Brigham and Houston, 2004)[13];(Rasyid, 2015)[2 ]. Profitability as measured by the ROE proxy is the ratio between Net Profit and the amount of equity in the company. Where if the net profit obtained by the company is higher, the better the position of the company with a high level of profit. Profitability in this study is Return On Equity (ROE) with increasing net income compared to the equity capital used.

\section{c. Dividend Policy}

Dividend policy (measured by the DPR proxy) is the percentage of profit paid to shareholders in the form of cash dividends, maintaining dividend stability over time. distribution of stock dividends, and share repurchases (Horne, 2008)[15]. Dividend Policy in this study is the Dividend Payout Ratio (DPR) with the formula for calculating dividends per share / earnings per share $\mathrm{x}$ $100 \%$ 


\section{d. Conceptual Framework}

Figure 1. Conceptual framework

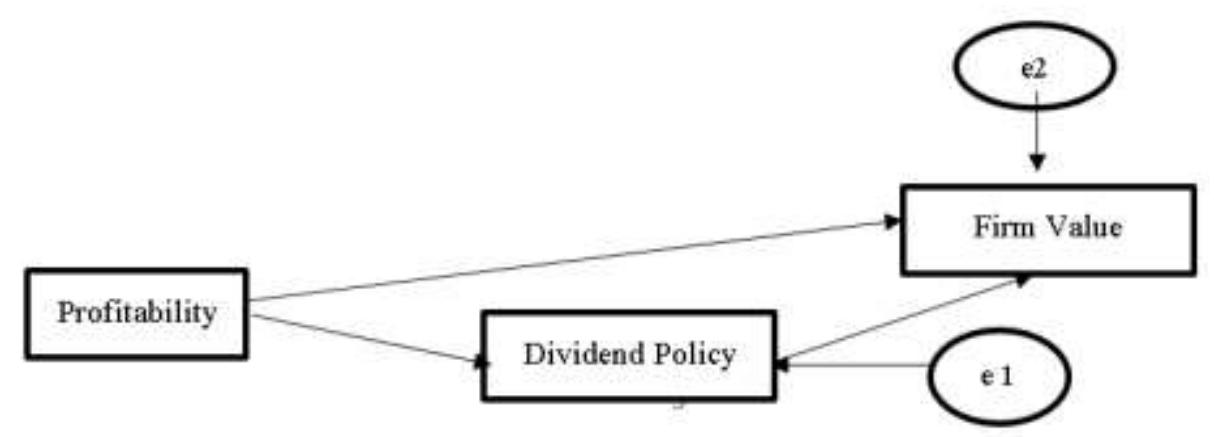

$$
\text { Description: } \begin{aligned}
\text { X1 (Profitability) } & \rightarrow \text { Independent variable } \\
\text { Z (Dividend Policy) }) & \rightarrow \text { Intervening variable } \\
\text { Y } & \rightarrow \text { Dependent variable }
\end{aligned}
$$

\section{e. Hypothesis}

Based on the abovementioned framework, the hypotheses proposed in this study are:

H1: There are positive and significant effects of profitability on dividend policy.

$\mathrm{H} 2$ : There are positive and significant effects of dividend policy on corporate value.

H3: There are positive and significant effects of profitability on corporate value.

H4: There are positive and significant effects of profitability on corporate value through

$$
\text { dividend policy }
$$

\section{RESEARCH METHODS}

\section{a. Population and Sampling Techniques}

Population of 167 companies. Determination of the number of samples using purposive sampling method, in order to obtain a sample of 27 manufacturing companies so that the data obtained is 108 data. There are as many as 27 companies namely: Astra Motor International (ASII), Astra Otoparts (AUTO), Sepatu Bata (BATA), Chitose International (INTP), Charoen Pokphand (CPIN), Ekadharma International (EKAD), Gudang Garam (GGRM), Hanjaya Mandala Sampoerna (HMSP), Indofood CBP Sukses Makmur (ICBP), Impack Pratama Industri (IMPC), Indofood Sukses Makmur (INDF), Indocement Tunggal Prakarsa (INTP), Kabelindo Murni (KBLM), Kino Indonesia (KINO), Kalbe Farma (KLBF), Multi Bintang Indonesia (MLBI), Supreme Cable Manufacturing \& Commerce (SCCO), Sido Muncul (SIDO), Sekar Laut (SKLT), Semen Baturaja (SMBR), Selamat Sampurna (SMSM), Tunas Alfin (TALF), Surya Toto Indonesia (TOTO), Trisula International (TRIS), Tempo Scan Pasific (TSPC), Unilever Indonesia (UNVR), dan Wijaya Karya Beton (WTON).

\section{b. Research variable}

There are 1 variable in this study, namely:

1. Independent Variable 


\section{Dependent variable:}

- $\quad$ Firm value $(\mathrm{Y})$

Firm value can be measured by the formula

$\mathrm{PBV}=$ market price per share $\times 100 \%$

Book value per share

- $\quad$ Profitability (X1)

Profitability can be measured by the formula:

$$
\mathrm{ROE}=\text { Laba Bersih } \times 100 \%
$$

\section{Intervening variable:}

- $\quad$ Dividend Policy (Z)

Dividend policy can be measured by the formula

$D P R=$ dividends per share $x 100 \%$

earning per share

\section{c. Technical Analysis}

In this study, the technique used is Path Analysis to determine the direct or indirect effect of various variables using SPSS software. Chandrarin, G (2017)[15] Hypothesis testing uses the t test (partial) if the probability is 0.05, the hypothesis is rejected, meaning that there is no significant effect of the independent variable on the dependent variable. And if the probability $<0.05$, then the hypothesis is accepted, it means that there is a significant effect of the independent variable on the dependent variable. In this research, there are 2 (two) structural equations, namely:

$$
\begin{aligned}
& \mathbf{Z}=\mathbf{X} \mathbf{1}+\mathbf{E} \mathbf{1} \\
& \mathbf{Y}=\mathbf{X} \mathbf{1}+\mathbf{Z}+\boldsymbol{\varepsilon} \mathbf{2}
\end{aligned}
$$

Information:

$\begin{array}{ll}\mathrm{X} 1 & =\text { Profitability }(\mathrm{ROE}) \\ \mathrm{Z} & =\text { Dividend Policy }(\mathrm{DPR}) \\ \mathrm{Y} & =\text { Firm value }(\mathrm{PBV}) \\ \varepsilon & =\text { The influence of other factors }\end{array}$

\section{RESEARCH RESULTS AND DISCUSSION}

\subsection{Path Analysis}

The first equation is to determine the relationship between variables, namely profitability, company size, and company growth on capital structure which can be shown in the following tables: 
Table 3. Profitability, dividend policy, firm value,

\begin{tabular}{|c|c|c|c|c|c|}
\hline Regression & $\begin{array}{l}\text { Direct } \\
\text { Influence }\end{array}$ & $\begin{array}{l}\text { Sig } \\
\text { Value }\end{array}$ & Indirect Effect & Total Effect & $\begin{array}{l}\text { Hipothesis accepted / } \\
\text { rejected }\end{array}$ \\
\hline $\begin{array}{l}\text { Profitability }(\mathrm{X} 1) \quad \rightarrow \quad \text { Dividend } \\
\text { Policy }(\mathrm{Z})\end{array}$ & 0.323 & 0.001 & & & H1 Accepted \\
\hline $\begin{array}{l}\text { Dividend Policy }(\mathrm{Z}) \rightarrow \text { Firm Value } \\
(\mathrm{Y})\end{array}$ & 0.229 & 0.004 & & & H2 Accepted \\
\hline $\begin{array}{l}\text { Profitability }(\mathrm{X} 1) \rightarrow \text { Firm Value } \\
(\mathrm{Y})\end{array}$ & 0.539 & 0.000 & & & H3 Accepted \\
\hline $\begin{array}{l}\text { Profitability } \quad(\mathrm{X} 1) \rightarrow \quad \text { Dividend } \\
\text { Policy }(\mathrm{Z}) \rightarrow \text { Firm Value }(\mathrm{Y})\end{array}$ & 0.539 & & $\begin{array}{lll}(0.539) & \mathrm{x} & (0.229) \\
0.1234 & & \end{array}$ & $=\begin{array}{l}0.539 \\
0.1234=0.6624\end{array}$ & H4 Rejected \\
\hline
\end{tabular}

Source: processed data

So that the structural equation model is as follows:

$$
\begin{array}{cc}
\mathrm{Z}=0.323 \mathrm{X} 1+\mathrm{e} 1 & \mathrm{e} 1=0.9466 \\
\mathrm{Y}=0.539 \mathrm{X} 1+0.229 \mathrm{Z}+\mathrm{e} 2 & \mathrm{e} 2=0.7602 \\
\mathrm{R}_{\mathrm{m}}^{2}(\text { Determination Coefisient })=1-(0.9466) 2(0.7602)=1-(0.89605156)(0.57790404) \\
=0.4822 & =1-0.5178318165723024
\end{array}
$$

The diversity of data that can be explained by the model is $48.22 \%$ or the information contained in the data is $48.22 \%$ explained by the model, while the $51.78 \%$ is explained by other variables outside of this study.

Based on table 3, the t statistic results show that the coefficient of the effect of profitability on dividend policy value is 0.323 with a significance level of 0.001 which is smaller than 0.05 . This shows that the profitability variable has a positive and significant effect on dividend policy. The t statistic results show that the coefficient of the effect of dividend policy on firm value is 0.229 with a significance level of 0.004 which is smaller than 0.05 . This shows that dividend policy variable has a positive and significant effect on firm value. The t statistic results show that the coefficient of the effect of probability on firm value is 0.539 with a significance level of 0.000 which is smaller than 0.05 . This shows that probability variable has a strong positive and significant effect on firm value. And the value of the direct effect, which is 0.539 is greater than value ot the indirect effect, which is 0.1234 meaning that the direct effect is greater than the indirect effect, this result shows that no influence of profitability on firm value through dividend policy.

\subsection{Discussion}

\section{a. Profitability have a positive effect on dividend policy.}

The coefficient of the effect of profitability on dividend policy 0.323 with a significance level of 0.001 , which is smaller than 0.05. This shows that the profitability variable has a positive and significant effect on the dividend policy variable. This means that the greater the level of profitability akan maximize earning profit company, maximize probability to divide earning profit to dividend policy.The results of this study are supported by research by Rasyid(2015)[2];Handayani(2018); stated that profitability has a positive and significant effect on dividend policy.

\section{b. Profitability, and dividend policy have a positive effect on firm value.}

The coefficient of the effect of profitability on firm value is 0.539 with a significance level of 0.000 , and The coefficient of the effect of dividend policy on firm value is 0.229 with a signifinance level of 0.004 . Ini berarti bahwa profitabilitas sangat berpengaruh terhadap firm value beserta dividend policy juga berpengaruh terhadap firm value.

The results of this study are in line with research conducted by Rasyid(2015)[2]; Handayani(2018); state that profitability has a positive and significant effect on firm value. and also dividend policy a positive significant effect on firm value.

\section{c. Profitability have no effect on firm value through dividend policy.}

Result of influence the indirect variables of profitability on firm value through dividend policy are smaller than the direct effect. This means that the dividend policy variable cannot mediate the effect of the variable profitability on firm value. Dividend policy cannot attract if for investor because investor prefer capital gains over cash dividends. 


\section{CONCLUSIONS AND RECOMMENDATIONS}

Based on the results of the research and discussion described in the previous chapter, it can be concluded that profitability has a positive and significant effect on firm value But only profitability have stronger effect, it should be used as efficiently and as best as possible to carry out its dividend policy and provide an exit effect for investors, but the synergy of dividend policy is less supportive so that only profitability which has a strong direct effect can contribute to increasing the influence on firm value. .

Profitability do not affect firm value through the dividend policy because the indirect effect is smaller than the direct effect. This means that the dividend policy cannot mediate the effect of profitability on firm value.

\section{REFERENCES}

1. Fama et al., (1978) Fama, E.F., 1978. The Effects of a Firm's Investment and Financing Decisions on the Welfare of its Security Holders. The American Economic Review, 68 (3), pp. 272-284.

2. Rasyid, A., dan Mahfudnurjamuddin, 2015. Effect of Ownership Structure, Company Size and Profitability on Dividend Policy and Manufacturing Company's value in Indonesia Stock Exchange, Australian Journal of Basic and Applied Sciences, 2015, 9(20), 618-624

3. Rao, dan Stevens (2007) Rao, A Theory of The Firm's Cost Capital, World Scientific Publishing Co. Pte. Ltd, Singapore

4. Thamrin, M. dan Mus, H.R., 2017 Effect of profitability and dividend policy on corporate governance and firm value: Evidence from Indonesian Manufacturing Sectors, IOSR Journal of Business and Management, 2017, 19(10), 66-74

5. Gordon, M. J., 1963. “Optimal Investment and Financing Policy.” Journal of Finance 18:2, 264-272.

6. Lintner, John. 1956. Distribution of Incomes of Corporation of Among Dividends, Retained Earnings, and Taxes, The American Review, May. 97-113.

7. Chen, L.J. dan Chen, S.J, 2011.'The influence of profitability on firm value with capital structure as the mediator and firm size and industry as moderators , Investment Management and Financial Innovation, vol 8(3), 2011

8. Octaviani, R.M dkk, 2019. The Effect Of Probability, Tax Avoidance And Information Transparency On Firm Value: An Empirical Study In Indonesia, International Journal Of Scientific \& Techonology Research Volume 8, issue 11

9. Hirdinis, M., 2019. Capital Structure and Firm Value Moderated by Profitability, International Journal Of Economics and Business Administration, 2019, vol 8(1), 174-191

10. Chandarin, G., 2017. Metode Riset Akuntansi Pendekatan Kuantitatif. Edisi 1, Jakarta: Penerbit Salemba.

11. Handayani, I. A. R. P, dan Ariyanto, D., dan Rasmini, N. K., dan Widanaputra, A. G. P. The Effect of Probability, Institutional Ownership on the Value of the Company with Dividend Policy as a Meditation, International Journal of Sciences: Basic and Apllied Research (IJSBAR), 2018, 41(1), 234-242.

13. Brigham, E.F. dan Houston J.F., 2007. Fundamentals of Financial. Management, Eleventh Edition, Thomson South-Western, United States of America

14. Sulastri, Yuliani, Agustina, 2018. The Effect Of Stock Ownership Structure, Capital Structure, And Profitability To Firm Value

In Manufacturing Company Sector In Indonesia Stock Exchange, International Journal Of Scientific \& Techonology Research,

vol 7(11), 187-192

15. Horne, J.C.V. dan Wachowicz, 2002, Fundamental of Financial Management, 13 th edition, Prentice Hall 
16. Shiem, J.K., dan Siegel, J.G.. 1998. Schaum's Outline of Theory and Problems of Financial Management, McGraw Hill.

\section{APPENDIX}

\section{Z (DIVIDEND POLICY) Intervening variable}

\begin{tabular}{|l|l|l|l|}
\hline \multicolumn{2}{|l|}{ Variables Entered/Removed } \\
\hline & & Variables & \\
Model & Variables Entered & Removed & Method \\
\hline 1 & Rank of ROE & & Enter \\
\hline a. Dependent Variable: Rank of DPR & \\
\hline \multicolumn{2}{|l}{ b. All requested variables entered. } \\
\hline
\end{tabular}

\begin{tabular}{|l|l|l|l|l|}
\hline \multicolumn{2}{|l|}{ Model Summary } & & Std. Error of the \\
\hline & & & Adjusted R Square & Estimate \\
\hline Model & R & R Square & 29.783656 \\
\hline 1 & $.323^{\mathrm{a}}$ & .104 & .096 & \\
\hline
\end{tabular}

\begin{tabular}{|c|c|c|c|c|c|c|}
\hline \multicolumn{7}{|c|}{ ANOVA $^{\mathbf{a}}$} \\
\hline \multicolumn{2}{|c|}{ Model } & Sum of Squares & df & Mean Square & $F$ & Sig. \\
\hline \multirow[t]{3}{*}{1} & Regression & 10935.488 & 1 & 10935.488 & 12.328 & $.001^{\mathrm{b}}$ \\
\hline & Residual & 94029.012 & 106 & 887.066 & & \\
\hline & Total & 104964.500 & 107 & & & \\
\hline
\end{tabular}

DIVIDEND POLICY $(Z)=$ PROFITABILITY $($ X1) + e1

FIRM VALUE (Y) = PROBABILITY (X1) + DIVIDEND POLICY $(\mathrm{Z})$ + e2 